\title{
Current Status and Future Forecast of the Number of Otolaryngologists in Korea
}

\author{
Jiyeon Lee ${ }^{\mathbb{D}}$, Jin Kook Kim ${ }^{\mathbb{D}}$, and Jae Hoon Cho ${ }^{\mathbb{D}}$ \\ Department of Otorhinolaryngology-Head and Neck Surgery, College of Medicine, Konkuk University, Seoul, Korea \\ 한국의 이비인후과 전문의 수 현황과 향후 예측 \\ 이지연 · 김진국 · 조재훈 \\ 건국대학교 의과대학 이비인후-두경부외과학교실
}

Received April 4, 2020

Revised June 1,2020

Accepted June 4, 2020

Address for correspondence

Jae Hoon Cho, MD, PhD, MPH

Department of Otorhinolaryngology-

Head and Neck Surgery,

College of Medicine,

Konkuk University,

120 Neungdong-ro, Gwangjin-gu,

Seoul 05029, Korea

Tel $+82-2-2030-5299$

Fax $+82-2-2030-7667$

E-mail jaehoon@kuh.ac.kr
Background and Objectives The number of otolaryngologists in Korea has increased rapidly in recent years. However, as the population is expected to decrease gradually, it is necessary to study the appropriate number of otolaryngologists.

Subjects and Method We counted the number of otolaryngologists certified annually and the number of currently active otolaryngologists, and estimated the retirement time from this data. In addition, the statistics from the National Statistical Office were used to survey the total population and the youth population under the age of 14 up to 2060. Finally, changes in the number of active otolaryngologists and the population per otolaryngologist were predicted by 2060 . Results The total number of otolaryngologists certified by 2020 was 4699 , and the number of active otolaryngologists in 2019 was 3950 . The average duration of retirement is about 36.5 years, and it is expected to be 40 years soon. Currently, $77.4 \%$ of otolaryngologists are practitioners, and 51.3\% are working in Seoul and Gyeonggi-do. In 2009, the number of people per otolaryngologist was about 17000 , whereas in 2019 it was sharply reduced to about 13000 . If 120 otolaryngologists are produced each year, it decreases to about 10000 by 2060 . However, if the number of new otolaryngologists is reduced to 100 per year, it can be maintained at around 12000 in 2060. In any case, however, the number of patients under 14 years of age cannot be prevented from falling sharply.

Conclusion It is necessary to adjust the number of otolaryngologists to account for population decline. Korean J Otorhinolaryngol-Head Neck Surgg 2021;64(2):77-85

Key Words Forecasting $\cdot$ Korea $\cdot$ Otolaryngology $\cdot$ Trends.

\section{서 론}

대한이비인후과학회는 1947년 창립되었으나 1959년까지는 전문적인 자격고시 없이 일정한 조건을 만족하면 이비인후과 를 전문과목으로 표방할 수 있는 자격을 주다가 이후 1960년 부터 본격적으로 자격고시를 시행하였다. ${ }^{1)}$ 초기에는 국립보 건원에서 주관하여 시행되었으나 1973년부터는 대한의학협회

This is an Open Access article distributed under the terms of the Creative Commons Attribution Non-Commercial License (https://creativecommons.org/licenses/by-nc/4.0) which permits unrestricted non-commercial use, distribution, and reproduction in any medium, provided the original work is properly cited.
의 관리하에 시행되고 있으며, 2020년까지 총 63회에 이르는 전문의 시험을 통해 모두 4699명의 이비인후과 전문의를 배 출하였다. ${ }^{1,2}$

한 명의 전문의를 만드는 과정에는 사회 전체적으로 막대 한 시간과 비용을 투입해야 한다. ${ }^{3)}$ 따라서 면밀한 수요조사에 따라 필요한 전문의의 수를 산정하고 이에 근거해서 학회 차 원의 장기적인 전문의 수련 계획이 정해져야 함에도 불구하고 지금까지는 주로 국가에 의해 일방적으로 시행되었다. ${ }^{4)}$ 이제 곧 대한민국의 전체 인구가 감소하고, 특히 이비인후과의 주요 환자군인 청소년층은 이미 급격한 감소세이다. ${ }^{5)}$ 따라서 이러 
한 인구변화의 고려 없이 이비인후과 전문의가 지금처럼 배출 되면 가까운 미래에 심각한 과잉공급에 봉착할 수 있다. 이는 현재 임상 진료를 하고 있는 이비인후과 의사들뿐만 아니라 앞 으로 배출될 후배 이비인후과 전문의들에게도 큰 부담이 될 것이며, 사회적으로는 불필요한 의료 인력 낭비가 될 수 있다.

이에 본 연구자들은 지금까지의 이비인후과 전문의 배출 현 황과 인구 변동에 따른 앞으로의 추이를 예측해보고 앞으로 의 방향에 대해 고민해보고자 하였다.

\section{대상 및 방법}

\section{이비인후과 전문의 배출 현황}

1952 2017년까지의 연도별로 배출된 이비인후과 전문의 수는 '대한이비인후과학회 50년사'와 '대한이비인후과학회 70년사’의 '연도별 전문의 지원자 및 합격률' 표를 참조하였고, 2018 2020년까지의 배출된 수는 학회에 문의하였다. ${ }^{1,2}$

\section{이비인후과 전문의 현황 자료}

연도별 현역 이비인후과 전문의 수는 국가통계포탈(http:// kosis.kr/index/index.do)에서 제공하는 '종별 전문과목별 전 문의 현황' 자료와 '지역별 전문과목별 전문의 인원 현황' 자료 를 참조하였다. 여기서는 2009 2019년까지의 매해 4/4분기 의 자료가 제공되는데 각 연도의 $3 / 4$ 분기 자료를 해당 연도의 대표값으로 채택하여 분석하였다. '종별 전문과목별 전문의 현황에서는 근무장소에 따라 상급종합병원, 종합병원, 병원, 요양병원, 의원, 보건소 등으로 나누어져 현역 전문의 수가 정 리되어 있었고, '지역별 전문과목별 전문의 인원현황'에서는 전국을 17 개 지역으로 나누어 현역 전문의 수가 정리되어 있 었다.

\section{인구 현황 및 예측}

지역별 인구는 마찬가지로 국가통계포탈에서 ‘도시지역 인구 현황' 자료를 참조하였다. 17개 지역에 대해 2009 2018년까지 변화를 조사하였고, $3 / 4$ 분기 자료를 해당 연도의 대표값으로 사용하였다. 14세 이하 유소년의 인구도 추가로 조사하였다. 2019 2060년까지의 인구 예측치는 통계청에서 발간한 '장래 인구추계: 2015 2065년' 자료의 중위값 추정치를 따랐으며 전체 인구와 14 세 이하 유소년의 인구로 나누어 조사하였다.

\section{이비인후과 전문의 예측 자료}

본 예측에 있어 가장 문제는 특정 시점에 사망, 질병, 고령 등의 이유로 은퇴한 전문의 누적 총수에 관한 정확한 자료를 구할 수 없었다는 점이다. 대신 다음과 같은 공식을 사용하여
계산하였다.

은퇴한 전문의 누적 총수=배출된 전문의 누적 총수-현역 이비인후과 전문의 총수

전문의 배출 자료는 1960년 이후부터 있지만 연도별 현역 이 비인후과 전문의 수에 관한 자료는 2009 2019년까지만 있으 므로 이 기간에 은퇴한 전문의 누적 총수만 계산할 수 있었다. 2009년도까지 은퇴한 전문의 누적 총수는 475명이였으며 이 는 1979년까지 배출된 전문의 총수인 461명과 1980년까지 배 출된 505명의 사이 값이다(Fig. 1A). 따라서 2009년도까지는 평균적으로 전문의 취득 후 약 29.5년(=2009-1979.5)이 지나 은퇴하였다고 추정된다. 한편 2019년도까지 은퇴한 전문의 총수는 636명이였는데(Fig. 1B), 1982년까지 배출된 전문의 가 582명이고 1983 년까지 배출된 전문의가 684 명이므로, 이 때는 평균적으로 전문의 취득 후 약 36.5년(=2019-1982.5)이 지나 은퇴하였다고 추정된다. 2009년에 비해 2019년에는 평 균 7년을 더 진료하고 은퇴한 것이다. 전문의 취득 후 은퇴까 지 연수는 2009년 29.5년에서 30.5년(2010), 31년(2011), 32년 (2012), 33년(2013), 33년(2014), 33.5년(2015), 34년(2016), 34.5년(2017), 35.5년(2018), 36.5년(2019)으로 일정하게 증가 하는 추세라 2019년 이후로도 조금 더 증가할 가능성이 높다 (Fig. 1). 또한 최근 10년간 전문의 합격자수는 평균 117.8 명이 였다(Appendix 1). 이러한 자료를 근거로 다음과 같은 4가지 가능성 있는 예측 모델을 만들어 2060년까지의 현역 이비인 후과 전문의 수 변화를 추정하였다.

- 모델 1: 매해 120 명의 새로운 전문의를 뽑고, 전체 전문의 들이 전문의가 된 후 37 년째 은퇴

- 모델 2: 매해 120 명의 새로운 전문의를 뽑고, 전체 전문의 들이 전문의가 된 후 40년째 은퇴

- 모델 3: 매해 100 명의 새로운 전문의를 뽑고, 전체 전문의 들이 전문의가 된 후 37 년째 은퇴

- 모델 4: 매해 100 명의 새로운 전문의를 뽑고, 전체 전문의

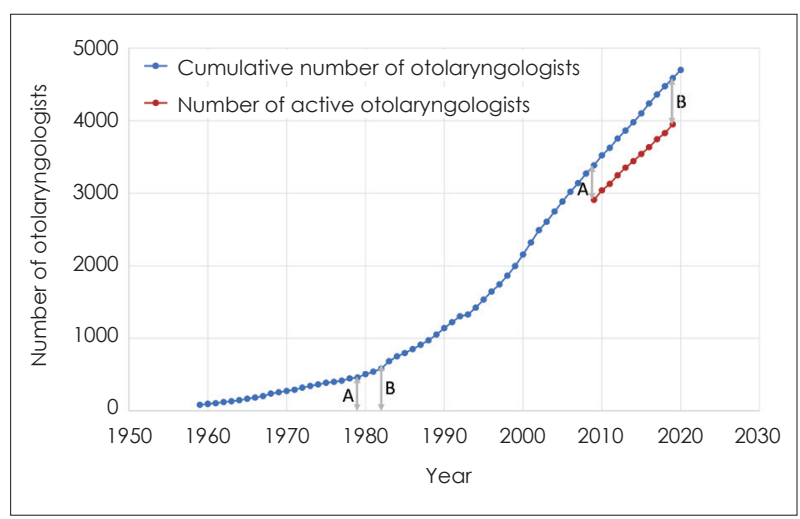

Fig. 1. Cumulative number of otolaryngologists and number of active otolaryngologists. A, B represent the number of otolaryngologists who retired by $2009(n=475)$ and $2019(n=636)$, respectively. 
들이 전문의가 된 후 40년째 은퇴

현역 전문의 수는 "그해까지 배출된 전문의 총수와 그해까 지 은퇴한 전문의 총수의 차이”로 정의하였다. 모든 계산은 Excel을 사용하여 진행하였고, 통계적 추정은 없었다. 또한 공개된 자료를 사용하였고 환자를 대상으로 한 연구가 아니 기 때문에 IRB 심의는 의뢰하지 않았다.

\section{결 과}

\section{이비인후과 전문의 배출 현황}

1960 1979년까지는 매해 평균적으로 18.0명의 이비인후과 전문의를 배출하다가, 1980 년부터 수가 급격히 증가하였는데 1993년까지 14년간 매해 평균 61.9명을 배출하였다. 이후 1994 년부터는 거의 매해 100 명 이상씩 배출되었고, 특히 2000년, 2001년, 2002년에는 각각 160명, 166명, 168명에 이르렀다. 이 후 차츰 감소하여 최근 10 년간은 평균 117.8 명이였다. 2020년까 지의 총 누적 총계는 4699명이다(Fig. 1, Appendix 1).

\section{이비인후과 전문의 현황 자료}

2019년 기준으로 현역 이비인후과 전문의는 모두 3950명이 었다. 의원 형태의 근무가 3058명으로 $77.4 \%$ 이며, 상급종합병 원과 종합병원에 근무하는 경우가 722 명(19.5\%), 그 외에 병원, 요양병원, 보건소 등에 근무하는 경우가 각각 102명(2.6\%), 38 명(0.9\%), 26명(0.6\%)이었다. 2009년에 현역 전문의가 2909명 이였던 것과 비교하면 10 년 사이에 1041 명이 증가한 수치이며, 그 중 의원의 증가폭이 863명으로 가장 컸다(Table 1).

지역별로 보면 전체 현역 전문의의 절반 이상인 2025명(51.3\%) 이 서울과 경기에 몰려 있었다. 그 다음으로는 부산(308명, 7.8\%), 대구(212명, 5.4\%), 인천(195명, 4.9\%), 경남(194명, 4.9\%) 순으 로 많았다. 2009년과 비교해 증가 비율은 세종(1050.0\%, 2012 년과 비교), 제주(64.3\%), 대전(50.0\%), 인천(44.4\%), 경기(43.6\%) 순으로 높았다. 2018년을 기준으로 현역 전문의 1 인당 인구는
충남이 22474명으로 가장 많았고 전남(20575명)과 경북(20412 명)도 2만 명이 넘었다. 반면 서울은 9079명으로 1만 명도 되 지 않았다. 전체적으로는 13474명이였다(Table 2).

\section{현역 이비인후과 전문의 수 예측}

현재와 같이 매해 120 명가량의 전문의를 매해 뽑는 경우 현 역 전문의 수는 지속적으로 증가해 2035년경에 정점에 이를 예 정이다(Fig. 2). 정년이 37세인 모델 1의 경우 2034년에 4582명 에 이르면 정년이 40세인 모델 2의 경우 2036년에 4678명에 이 른다. 2019년보다 632명에서 728명 가량 더 늘어난 수치다. 이 후 현역 전문의 수는 감소하기 시작하는데 모델 1의 경우 2057 년경에 이르러 4386명으로 유지되며 모델 2의 경우 2059년에 4482 명으로 유지된다. 전문의 정원을 100 명으로 줄이면 정점 은 위의 두 모델보다 5년가량 빠른 2031년에 도달하는데 정년 이 37세인 모델 3인 경우 4322명, 정년이 40세인 모델 4의 경우 4354명이 된다. 이는 2019년과 비교해 372명에서 404명 증가 한 수치다. 이후 마찬가지로 현역 전문의 수는 감소하기 시작 해 2057년이 되면 모델 3과 모델 4는 각각 3646명과 3678명 으로 유지되는데, 모델 1과 모델 2에 비해 700 800명가량 줄 어든 수치이다.

현역 전문의 1인당 인구를 계산해 보면 2019 2030년 까지 는 모든 모델에서 급격히 감소한다(Fig. 3). 2009년 현역 전문 의 1 인당 인구는 17110 명이지만, 모델 1 의 경우 2035 년이 되 면 11454명으로, 모델 2의 경우 2037년 11189명까지 감소한 다. 이후 약간 반등하지만 지속적으로 하락하여 2060년에는 각각 10303 명과 10082 명으로 감소할 것이다. 모델 3의 경우 2031년 12150명으로 정점을 찍고 이후 반등하여 2047년에는 13189 명까지 증가하다가 이후 차츰 감소하여 2060년에 12394 명이 된다. 모델 4도 모델 3과 거의 비슷한 추세를 보인다.

현역 전문의 1 인당 14 세 이하의 유소아 수의 경우 더욱 심 각한 하락세를 피할 수 없다(Fig. 4). 2009년 약 2836명이였지 만, 2020년에는 1591명, 2030년에는 1122 1174명이 되며, 이후

Table 1. Number of active otolaryngologists by hospital type

\begin{tabular}{cccccccc}
\hline Year & Total & Tertiary referral hospital & General hospital & Hospital & Nursing hospital & Clinic & Public health center \\
\hline 2009 & 2909 & 287 & 313 & 84 & 10 & 2195 & 20 \\
2010 & 3039 & 298 & 326 & 105 & 13 & 2279 & 18 \\
2011 & 3128 & 296 & 324 & 107 & 16 & 2351 & 34 \\
2012 & 3247 & 321 & 318 & 106 & 17 & 2440 & 45 \\
2013 & 3353 & 352 & 339 & 110 & 19 & 2497 & 35 \\
2014 & 3441 & 345 & 342 & 111 & 27 & 2581 & 32 \\
2015 & 3541 & 349 & 348 & 122 & 28 & 2662 & 30 \\
2016 & 3635 & 354 & 364 & 109 & 29 & 2758 & 19 \\
2017 & 3744 & 342 & 360 & 104 & 31 & 2879 & 25 \\
2018 & 3830 & 344 & 370 & 100 & 34 & 2958 & 22 \\
2019 & 3950 & 347 & 375 & 102 & 38 & 3058 & 26 \\
\hline
\end{tabular}




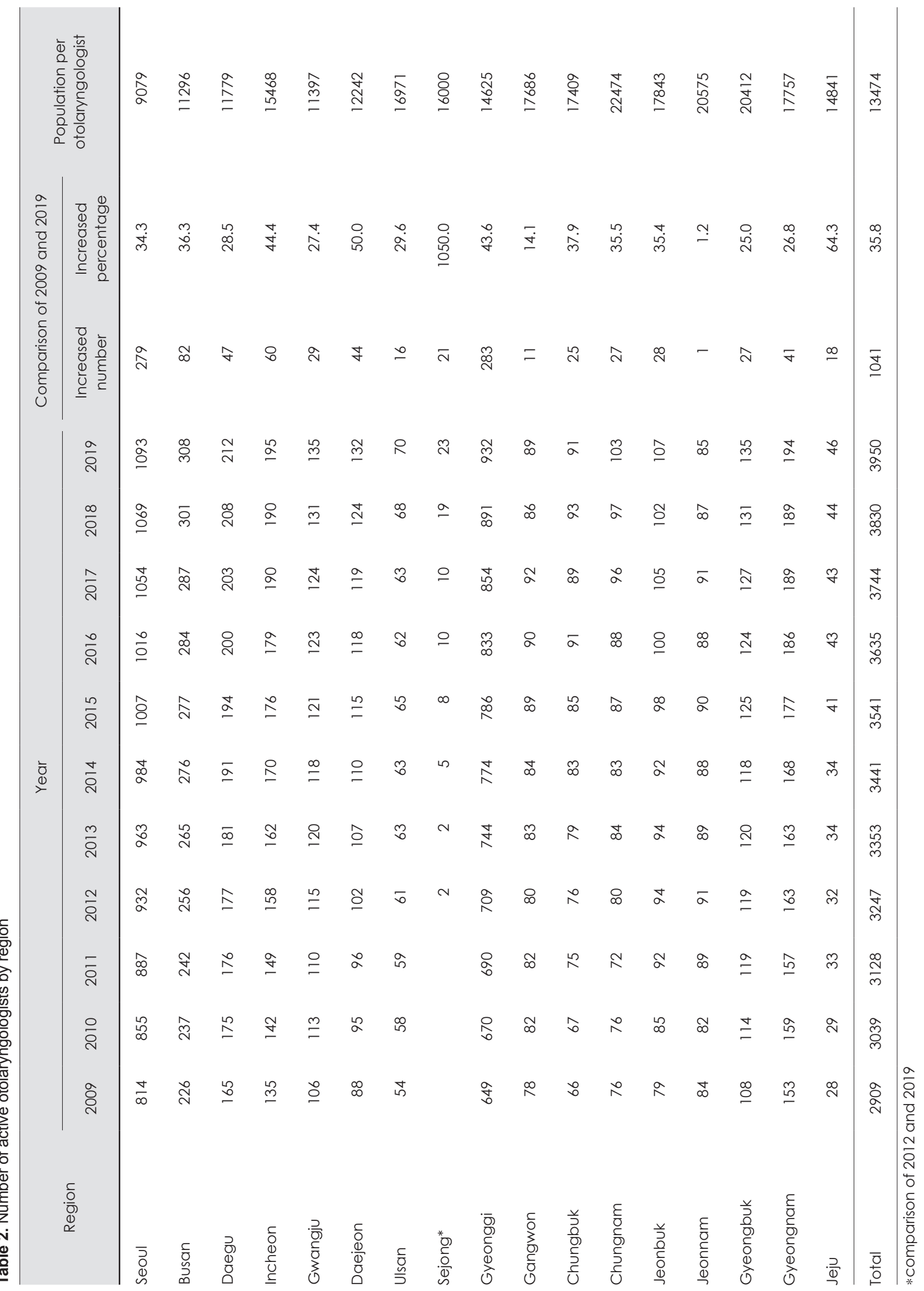


조금 증가하다가 지속적으로 하락하여 2060년에는 841 1034명 이 될 것이다. 4 가지 모델 모두 큰 차이는 없었다.

\section{고 찰}

의사들도 점차 고령화되어가고 있는데 2016년 보건복지부 의 의사면허 신고 현황에 따르면 의사면허 신고자의 $16 \%$ 가 60 세 이상의 고령이며, 특히 이비인후과는 개원을 가장 오랫 동안 하는 진료과로 알려져 있다. 실제로 2015년 발간된 국세

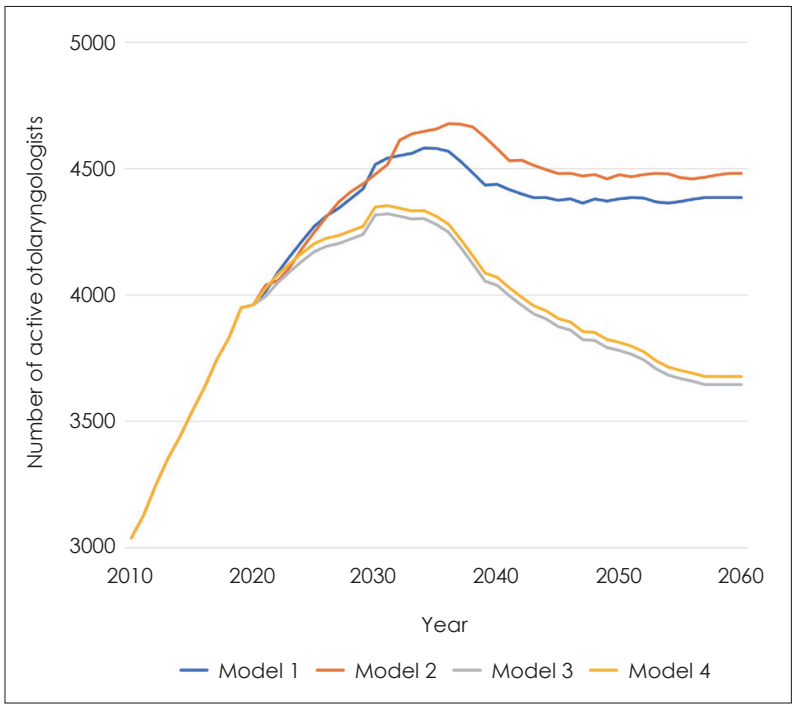

Fig. 2. The number of active otolaryngologists based on four different models (number of otolaryngologists certified every year/duration of practice). Model 1: (120/37 years), Model 2: (120/40 years), Model 3: (100/37 years), Model 4: (100/40 years).

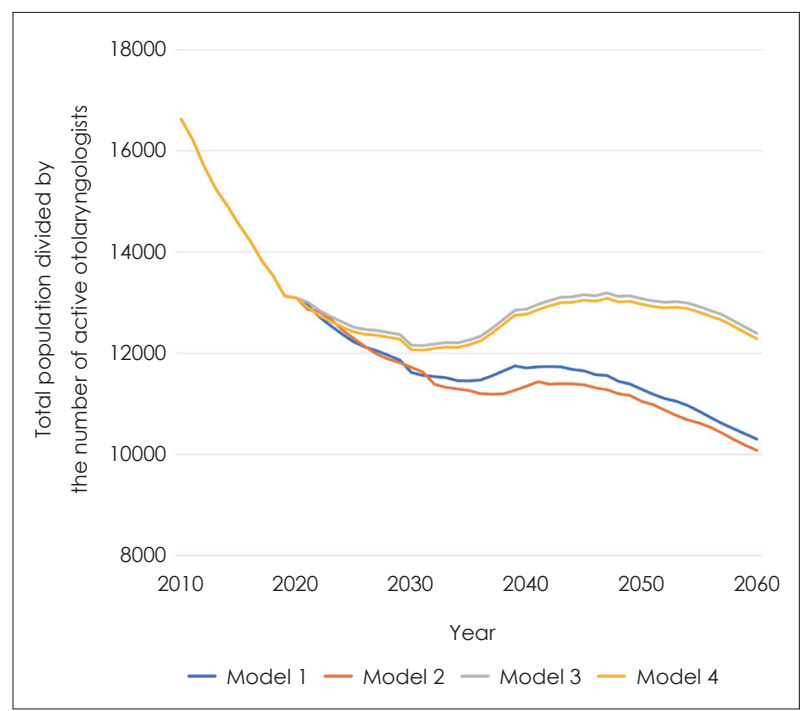

Fig. 3. Total population divided by the number of active otolaryngologists (number of otolaryngologists certified every year/duration of practice). Model 1: (120/37 years), Model 2: (120/40 years), Model 3: (100/37 years), Model 4: (100/40 years).
청의 자료를 보면 2013년 말 기준으로 20년 이상 장기 개원을 하는 비율이 평균 $17 \%$ 였는데 이비인후과는 $21.6 \%$ 로 진료과 중에서 가장 높은 수치였다. 향후에도 이러한 의사들의 고령 화 추세는 계속되리라 예측된다. 2018년 12월 의협신문에서 의사 850 명을 대상으로 한 설문조사를 보면 30 대 의사들의 경우 $16.6 \%$ 만이 70 세 이후 은퇴하겠다고 답변하였으나, 60 대 의사들의 경우 무려 $81.5 \%$ 가 70세 이후 은퇴를 계획하고 있 었다. 즉, 젊은 의사들은 조기에 은퇴하는 것을 목표로 하고 있었으나 막상 나이가 들어서는 은퇴를 늦추는 상황이다. 본 연구에서도 비슷한 경향을 보였는데, 2009년도에는 이비인후 과 전문의들이 전문의 취득 후 평균 약 29.5년 지나서 은퇴하 였는데, 2019년에는 그 시기가 36.5년으로 급격히 증가하였다. 전문의를 취득하는 나이가 최소 31 세인 점을 감안하면 현재 이비인후과 의사들의 평균 은퇴 나이는 $67.5(=36.5+31)$ 세보다 2 3세 더 많은 70세 정도로 추정되며, 2009년도에 비해 2019 년도에 평균 은퇴 나이가 급격히 증가하는 것을 감안하면 앞 으로도 은퇴 나이는 상당 기간 더 증가할 것이다. 이렇게 은퇴 나이가 증가하는 이유는 노인들의 건강상태가 좋아진 원인도 있겠지만, 의사들의 재정적 어려움도 원인이라 추정된다.) 이 러한 재정적 어려움은 만성적인 저수가 정책과 무분별한 의 사수 증가에 있다. ${ }^{78}$

본 연구의 목적은 다양한 가정하에 미래의 이비인후과 전 문의 수를 예측해보고 필요한 정책을 마련하는 것이다. 현재 처럼 120 명가량의 전문의를 매해 선발하고 전문의 취득 후 40년 후에 은퇴한다고 가정하면 앞으로 15년 동안 현역 전문 의 수는 꾸준히 늘어 4700 명가량 되며, 이는 현재보다 700명

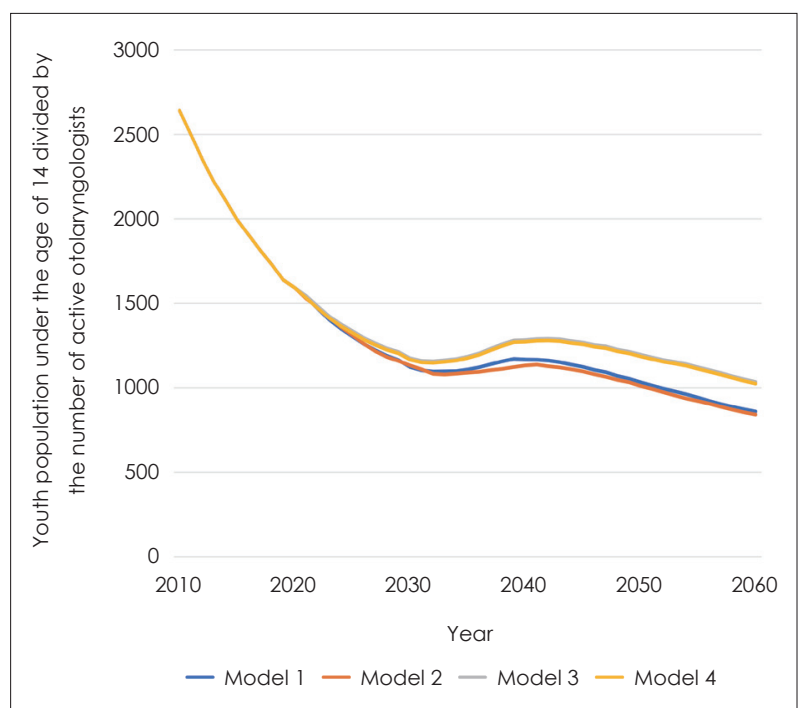

Fig. 4. Youth population under the age of 14 divided by the number of active otolaryngologists (number of otolaryngologists certified every year/duration of practice). Model 1: (120/37 years), Model 2: (120/40 years), Model 3: (100/37 years), Model 4: (100/40 years). 
이상 증가한 숫자이다. 이후 조금씩 감소하여 2045년에 이르 러 4500명가량을 유지하게 된다. 더욱 큰 문제는 우리나라 의 인구 감소이다. 통계청의 예측에 따르면 우리나라 인구는 2032년 약 52525000명으로 정점을 찍은 뒤 서서히 감소하는 데 2045년경이 되면 감소 속도가 점점 빨라지고 2060년이 되 면 약 4518800명으로 줄어든다(Appendix 2). 따라서 2045년 이후 전문의 수가 유지된다고 하여도 전문의 1 인당 인구는 꾸 준히 감소하게 된다. 현재 전문의 1 인당 약 13000 명꼴인데, 2060년이 되면 약 10000 명으로 줄어든다. 특히 더 우려스러 운 점은 유소아들이다. 현재 전문의 1 인당 14 세 이하 유소아 인구가 약 2800명인데 2060년이 되면 약 850명이 된다. 현재 의 약 $30 \%$ 수준이 되는 것이다. 이비인후과 질환의 특성상 유 소아의 환자의 비율이 높은데, 미래에는 유소아 인구의 급격 한 감소로 심각한 환자 수의 감소가 예상된다.

결국 해결책은 전문의 배출 수를 적절히 조절하는 것이다. 배출 수를 100 명으로 줄이고 이들이 전문의 취득 후 40년 뒤 은퇴한다 가정하면 10 년 후 현역 전문의 수가 약 4350명으로 최대가 되며, 이후 지속적으로 감소해 2060년경에는 3700명 정도로 유지될 수 있다. 이는 120 명을 배출할 때보다 800 명가 량 줄어든 수치이다. 전문의 1 인당 인구도 2060년 약 12300 명 으로 120 명을 배출하는 것과 비교하여 2300명 정도 증가한다. 다만, 유소아들의 경우 전문의 100 명을 배출하여도 감소 폭을 줄일 수 없었다. 은퇴 시기도 현역 전문의 수에 영향을 준다. 전 문의 획득 후 40 년째 은퇴하는 것은 37 년째 은퇴하는 것에 비 해 현역 전문의 수를 증가시키는데, 그 정도는 전문의 배출 수 에 따라 크게 다르다. 전문의 배출 수가 120 명일 경우에는 약 100 명 정도 증가시키는 효과가 있지만, 전문의 배출 수가 100 명인 경우에는 약 30 명 정도로 줄어든다. 은퇴 시기는 전문의 수와 밀접한 관계가 있으리라 생각된다. 즉, 현역 전문의 수가 많아져 의사들의 경제적 지위가 하락하면 은퇴 시기를 늦춰 더욱 오래 일해야 하고, 이는 현역 전문의 수를 더욱 증가시키 는 악순환으로 이어질 가능성이 높다. 반면 현역 전문의 수가 줄어들면 경제적 지위가 상승하면서 더욱 빨리 은퇴할 수 있 게 되고, 이는 남아있는 현역 전문의들의 수입을 증가시키는 선순환을 만들 수 있다.

이비인후과 전문의 수는 80년대 이전까지는 평균 20명 미 만의 소수만 배출되다가 80년대 들어서 평균 60명 이상씩 배 출하였고, 94 년 이후에는 평균 100명 이상이 되었다. 특히 2000 년 초반에 160 명 이상으로 급증하다가 감소하였다. ${ }^{1,2)}$ 이후 2013 2018년까지 전공의 정원구조 합리화 정책이 실시되었 다. ${ }^{4}$ 배경으로는 의사 배출이 2008년 3887명에서 2012년 3208 명으로 약 700 명 감소했는데, 오히려 전공의 정원은 수도권 등 의 병상 증가로 2008년 약 3900명에서 2012년 약 4000명으
로 증가해서 약 800 명 정도가 초과되었기 때문이었다.) 여기 에 더해 소위 인기과목 및 수도권 지역에 지원자가 몰려 비인 기과 및 지방의 수련병원에 전공의가 모자랐던 것도 이유였 다." ${ }^{4)}$ 이 정책으로 인해 이비인후과의 전공의 선발은 현재 104 명으로 줄었고, 2016년 135명까지 배출되었던 전문의가 2020 년에는 113 명까지 줄었다. 앞으로 본 정책이 지속될 경우 조만 간 전문의 배출 수를 매년 100 명 초반으로 맞출 수 있을 것이 고, 이는 장기적인 이비인후과 전문의 수 유지에 매우 중요한 갈림길이 될 것이다.

본 연구에 몇 가지 한계가 있음을 밝힌다. 첫째, 이비인후과 의사의 현실을 전문의 숫자라는 측면에서만 분석하였다. 현실 적으로 우리의 미래는 정부의 의료 정책, 각종 질환의 유병률 등락, 새로운 의료 기술 등장 등 여러 요인에 의해 영향을 받 을 것이다. 둘째, 현역 이비인후과 의사를 제외하고 모두 은퇴 하였다고 가정하였으나 사실은 연구직, 기업활동 등 비임상분 야에 종사할 수도 있으며, 임시 휴직 후 복귀할 가능성도 있 다. 셋째, 현재 반 이상의 이비인후과 전문의가 서울과 경인지 역에 몰려 있으므로 전체적인 전문의 수 조절과 함께 전문의 수 감소로 발생할 수 있는 서울·경기 외 지역의 의료 공백에 대한 정책적인 해결 등 다각적인 접근이 필요할 것이다.

결론적으로 현재까지 배출된 이비인후과 전문의 수와 점차 감소하는 우리나라의 인구를 고려해 보았을 때 향후 이비인 후과 전문의 배출 수를 100 명 정도로 관리할 필요가 있겠다.

\section{Acknowledgments}

None.

\section{Author Contribution}

Conceptualization: Jae Hoon Cho, Jin Kook Kim. Data curation: Jae Hoon Cho, Jiyeon Lee. Investigation: Jae Hoon Cho. Methodology: Jae Hoon Cho, Jiyeon Lee. Project administration: Jin Kook Kim. Writing — original draft: Jiyeon Lee, Jae Hoon Cho. Writingreview \& editing Jiyeon Lee, Jae Hoon Cho.

\section{ORCIDs}

Jae Hoon Cho https://orcid.org/0000-0002-2243-7428 Jiyeon Lee https://orcid.org/0000-0002-3427-7863

Jin Kook Kim https://orcid.org/0000-0003-4245-6252

\section{REFERENCES}

1) 김경래, 김민식, 김영호, 김용재, 김용환, 민헌기 등. 8 부 교육 및 연구. In: 최종욱. 대한이비인후과학회 50년사. 50 년사 편집위원회: 대한이비인후과 학회; 1997. p.204-205.

2) 김동영, 김수환, 김창훈, 박시내, 이세영, 임재열 등. 8 부 교육 및 연구. In: 김진국. 대한이비인후과학회 70년사. 70 년사 편집위원회: 대한이비인후과 학회; 2017. p.225-226.

3) 안은배, 정한나, 김한경, 김경식, 정성수, 허혜승 (2020). 의사양성 비용 추계 및 공공지원 방안 연구. 대한의사협회 의료정책연구소 연구보고서, 대한의사협회, 1-259.

4) 이윤성, 이수곤, 박중신, 엄중식, 이길연, 오민정 등. (2017), 전공의 
정원정책 수립을 위한 전문의 인력 수요 추계 연구. 보건복지부/ 대한의학회.

5) 통계청 보도자료 “장래인구추계: 2015-2065년”. 2016년 12월 8일. 통계청.

6) 최선. 60 대 이상 봉직의 폭발적 증가 “비자발적 정년 연장”. MedicalTimes: 2015년 5 월 28 일, Available from: URL: http:// www.medicaltimes.com/News/1097331
7) 김홍식. 건강보험 저수가 문제와 왜곡되는 의료환경(상). MedicalTimes: 2014년 5월 8일, Available from: URL: https://www. medicaltimes.com/Users/News/NewsView.html?ID=1089754

8) 음상준. 한국 의사 수 증가율 $56 \% \ldots$ OECD 평균 3 배. Dailymedi: 2013년 11월 21일, Available from: URL: http://dailymedi.com/ detail.php?number $=774045$ 


\section{Appendix 1}

Number of otolaryngologist discharges each year

\begin{tabular}{|c|c|c|c|c|c|}
\hline $\begin{array}{c}\text { Number of } \\
\text { certification tests }\end{array}$ & Year & $\begin{array}{c}\text { Number of } \\
\text { otolaryngologists certified }\end{array}$ & $\begin{array}{c}\text { Number of } \\
\text { certification tests }\end{array}$ & Year & $\begin{array}{c}\text { Number of } \\
\text { otolaryngologists certified }\end{array}$ \\
\hline & $1952-59$ & 84 & 33 & 1990 & 89 \\
\hline 1 & 1960 & 11 & 34 & 1991 & 82 \\
\hline 2 & 1960 & 4 & 35 & 1992 & 82 \\
\hline 3 & 1961 & 6 & 36 & 1993 & 23 \\
\hline 4 & 1962 & 17 & 37 & 1994 & 95 \\
\hline 5 & 1963 & 11 & 38 & 1995 & 110 \\
\hline 6 & 1964 & 15 & 39 & 1996 & 111 \\
\hline 7 & 1965 & 19 & 40 & 1997 & 99 \\
\hline 8 & 1966 & 16 & 41 & 1998 & 122 \\
\hline 9 & 1967 & 20 & 42 & 1999 & 131 \\
\hline 10 & 1968 & 36 & 43 & 2000 & 160 \\
\hline 11 & 1969 & 17 & 44 & 2001 & 166 \\
\hline 12 & 1970 & 18 & 45 & 2002 & 168 \\
\hline 13 & 1971 & 17 & 46 & 2003 & 117 \\
\hline 14 & 1972 & 29 & 47 & 2004 & 141 \\
\hline 15 & 1973 & 23 & 48 & 2005 & 137 \\
\hline 16 & 1974 & 20 & 49 & 2006 & 135 \\
\hline 17 & 1975 & 25 & 50 & 2007 & 119 \\
\hline 18 & 1976 & 13 & 51 & 2008 & 131 \\
\hline 19 & 1977 & 15 & 52 & 2009 & 114 \\
\hline 20 & 1978 & 32 & 53 & 2010 & 137 \\
\hline 21 & 1979 & 13 & 54 & 2011 & 104 \\
\hline 22 & 1980 & 44 & 55 & 2012 & 128 \\
\hline 23 & 1981 & 35 & 56 & 2013 & 111 \\
\hline 24 & 1982 & 42 & 57 & 2014 & 115 \\
\hline 25 & 1983 & 102 & 58 & 2015 & 122 \\
\hline 26 & 1984 & 67 & 59 & 2016 & 135 \\
\hline 27 & 1985 & 45 & 60 & 2017 & 125 \\
\hline 28 & 1986 & 56 & 61 & 2018 & 114 \\
\hline 30 & 1987 & 59 & 62 & 2019 & 111 \\
\hline 31 & 1988 & 62 & 63 & 2020 & 113 \\
\hline 32 & 1989 & 79 & & Total & 4699 \\
\hline
\end{tabular}




\section{Appendix 2}

Korea's Population Change. The orange part represents the population of children under the age of 14

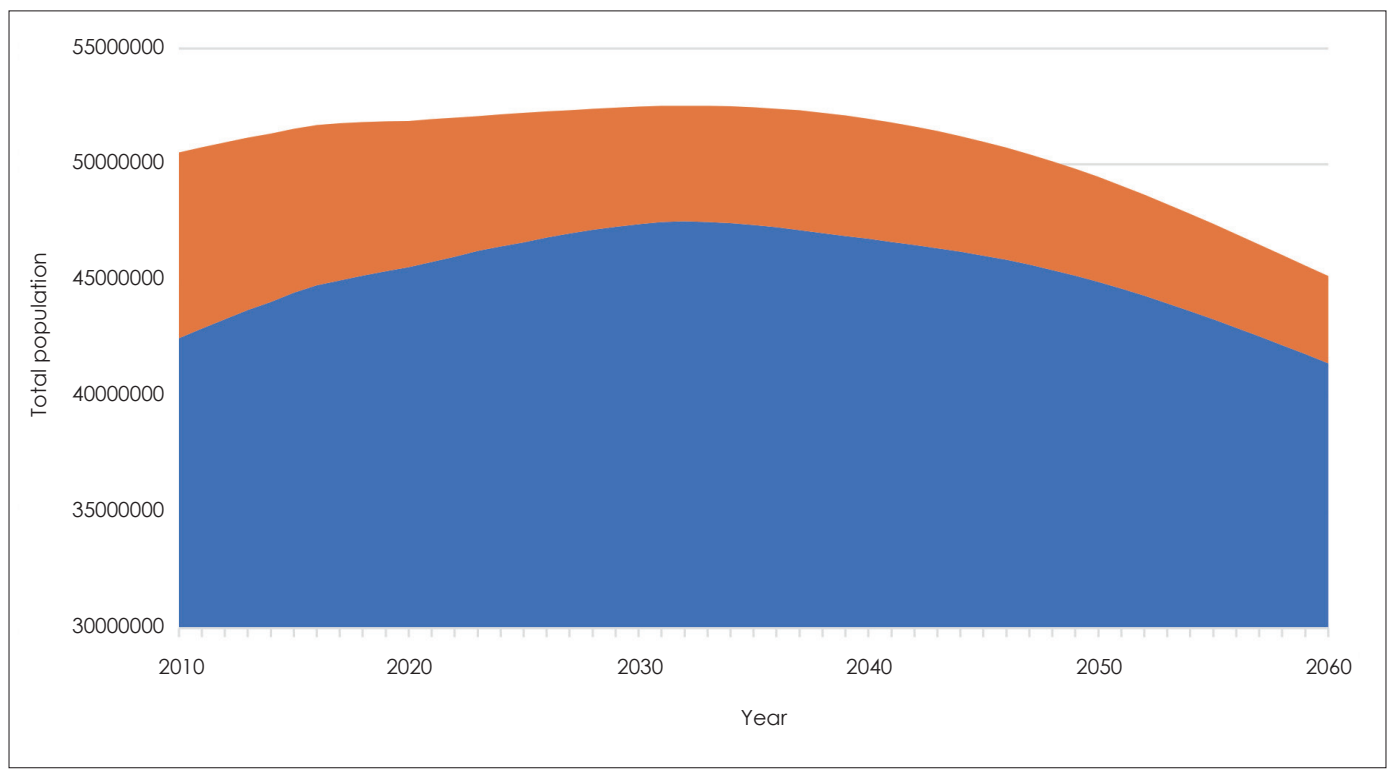

